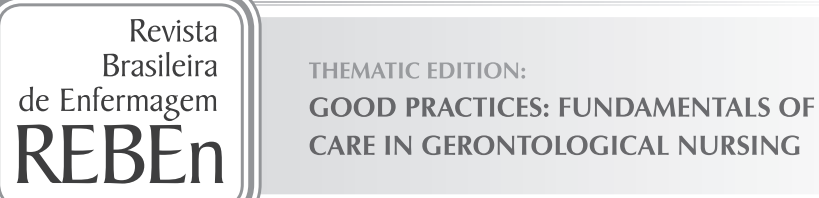

\title{
Nursing diagnosis in older adults with chronic kidney disease on hemodialysis
}

\author{
Diagnósticos de enfermagem em idosos com doença renal crônica em hemodiálise \\ Diagnósticos de enfermería en ancianos con enfermedad renal crónica en hemodiálisis
}

\section{Mayara Cristina Debone', Elisângela da Silva Nunes Pedruncci', Maristela do Carmo Peterossi Candido", Sueli Marques', Luciana Kusumota'}

' Universidade de São Paulo, Ribeirão Preto Nursing School. Ribeirão Preto, São Paulo, Brazil.

"Universidade de São Paulo, Ribeirão Preto Medical School, Hospital das Clínicas. Ribeirão Preto, São Paulo, Brazil.

\section{How to cite this article:}

Debone MC, Pedruncci ESN, Candido MCP, Marques S, Kusumota L. Nursing diagnosis in older adults with chronic kidney disease on hemodialysis. Rev Bras Enferm [Internet]. 2017;70(4):800-5. [Thematic Edition “Good Practices: Fundamentals of care in Gerontological Nursing"] DOI: http://dx.doi.org/10.1590/0034-7167-2017-0117

\section{Submission: 02-15-2017 Approval: 04-02-2017}

\section{ABSTRACT}

Objective: To identify the main nursing diagnoses (NSs) in older adult patients under hemodialysis treatment. Method: Exploratory research using case studies in data collection performed by interview and physical examination of older adults, in the first semester of 2016. Were included twenty-eight older adults undergoing chronic hemodialysis treatment who met the selection criteria. The analysis followed two steps (RISNER, 1990): Phase I - Data analysis and synthesis; and Phase II Establishment of nursing diagnoses using the taxonomy of NANDA-I (2015). Results: The total of NSs was 110, averaging 3.9 per patient. It was listed seven different NSs, and both the Risk of infection and the Volume of excessive liquids appeared on all patients $(28 ; 100 \%)$, and risk of electrolyte imbalance, in $26(96.8 \%)$ older adults, being considered as main NSs. Conclusion: Such results can help systematize the care of older people who are undergoing hemodialysis treatment.

Descriptors: Older adults; Kidney Dialysis; Nursing; Nursing Diagnosis; Chronic Kidney Failure.

\section{RESUMO}

Objetivo: Identificar os principais diagnósticos de enfermagem (DEs) em pacientes idosos em tratamento hemodialítico. Método: Pesquisa exploratória utilizando estudos de casos na coleta de dados realizada por entrevista e exame físico dos idosos, no primeiro semestre de 2016. Foram incluídos 28 idosos em tratamento crônico por hemodiálise que atenderam aos critérios de seleção. A análise seguiu duas etapas (RISNER, 1990): Fase I - Análise e síntese dos dados; e Fase II - Estabelecimento dos diagnósticos de enfermagem utilizando a taxonomia da NANDA-I (2015). Resultados: O total de DEs foi de 110, com média de 3,9 por paciente. Foram elencados sete DEs diferentes, sendo que tanto o Risco de infecção quanto o Volume de líquidos excessivo apareceram em todos os pacientes $(28 ; 100 \%)$, e Risco de desequilíbrio eletrolítico, em $26(96,8 \%)$ idosos, sendo considerados como principais DEs. Conclusão: Tais resultados podem colaborar na sistematização da assistência do idoso em tratamento hemodialítico.

Descritores: Idoso; Diálise Renal; Enfermagem; Diagnóstico de Enfermagem; Insuficiência Renal Crônica.

\section{RESUMEN}

Objetivo: Identificar los principales diagnósticos de enfermería (DE) en ancianos que reciben tratamiento de hemodiálisis. Método: Estudio exploratorio que se utilizó de estudios de caso mediante entrevistas y examen físico en ancianos para la recolección de datos, llevado a cabo en el primer semestre de 2016. Del estudio, participaron 28 ancianos que recibían tratamiento de hemodiálisis y que estaban bajo los criterios de selección. El análisis de datos siguió dos etapas (RISNER, 1990): En la Fase I se hizo el análisis y la síntesis de los datos; y en la Fase II se establecieron los diagnósticos de enfermería empleando la taxonomía NANDA-I (2015). Resultados: Los DE fueron 110, con un promedio de 3,9 por paciente. Se eligieron siete DE distintos, siendo que tanto el Riesgo de infección como el Volumen de líquidos excesivo estaban presentes en todos los pacientes (28; $100 \%$ ), y el Riesgo de desequilibrio electrolítico en 26 ancianos $(96,8 \%)$, siendo considerados como principales DE. Conclusión: Los resultados pueden ayudar que se sistematice la asistencia al anciano que recibe tratamiento de hemodiálisis. Descriptores: Anciano; Diálisis Renal; Enfermería; Diagnóstico de Enfermería; Insuficiencia Renal Crónica.

CORRESPONDING AUTHOR Mayara Cristina Debone Email: madebone03@gmail.com




\section{INTRODUCTION}

The aging of the Brazilian population follows a global trend. We observe increased prevalence of chronic non-communicable diseases (CNCDs) accompanying this process, including chronic kidney disease (CKD), which has been singled out as a public health problem worldwide ${ }^{(1)}$.

CKD is defined by the presence of renal injury or reduced level of kidney function for three months or more, regardless of the diagnosis, because of physiological decline of glomerular function. Therefore, older adults are more susceptible to loss of kidney function, which occurs slowly and gradually, having its early phase asymptomatic due to the adaptive process of the kidney to this new condition ${ }^{(2-3)}$.

Loss of kidney function is usually secondary to Diabetes mellitus (DM) and Systemic Arterial Hypertension (SAH), which are common comorbidities in aging, justifying the growing number of these older adult patients undergoing hemodialysis treatment. According to the survey data of dialysis units in Brazil, the total estimated number of patients on dialysis, in 2013, was 100,397; of the prevalent patients, $90.8 \%$ were on hemodialysis and $31.4 \%$ had age $\geq 65$ years. Therefore, it is important for the basis of care for this patient profile to be well established, which, in addition to having all the physiological characteristics arising from the natural process of aging, is under hemodialysis treatment ${ }^{(3-4)}$.

Renal replacement therapy (RRT) should be adopted as a means of supplying part of disability presented by the CKD. Hemodialysis is a form of RRT, which is accomplished using blood filtering through a semi-permeable membrane (dialyzer or artificial kidney), where occur, basically, the exchange of fluids, electrolytes and metabolic products between the blood and the dialysate. To this end, it is necessary the presence of a central venous access catheter, arteriovenous fistulas or prostheses, in which the blood flows pump driven by a hemodialysis machine, runs through an extracorporeal extension and returns to the patient ${ }^{(5)}$.

Major signs and symptoms observed during treatment under hemodialysis are, among others, hypotension, hypertension, vasoconstriction, cramps, nausea and vomiting, imbalance syndrome, headache, itching, chest and lumbar pain. Also, there are reactions related to the dialyzer, including anaphylactic reactions, acute hemolysis - which, during dialysis, can be an emergency just like embolism, as it can cause air embolization and neurological dysfunction and acute cardiac as well as hypoxemia and arrhythmia by cardiovascular changes ${ }^{(5)}$.

Facing this complexity of the clinical pattern of these patients, it is the duty of every health professional - and, in this context, nurses - to identify and deal with the phenomena arising from the hemodialysis treatment, using strategic methods of holistic assistance of the patients, where all their needs are met. With the increase in life expectancy, it becomes a challenge to establish assistance methods aimed at the promotion and maintenance of the quality of life of the older people population ${ }^{(6)}$.

The nursing process (NP) is a welfare method that seeks to address this proposal. It consists of a healthcare model that contributes to the implementation of professional nursing as a science. NP can be composed of five steps: data collection, nursing diagnosis, care planning, implementation and evaluation. This technology favors the interdependent and interdisciplinary actions, as it consists in the use of a standardized language, facilitating communication between the nursing staff and other professionals. In addition, the nurse can follow, understand and continue the clinical reasoning and the work initiated by the nursing staff, thus favoring the optimization of care and greater safety to the patient ${ }^{(7-9)}$.

The preparation of nursing diagnoses (ND) as a step of NP is critical to raising significant problems from the collected data, enabling the identification of needs. Basic human needs $(\mathrm{BHN})$ as the theoretical model proposed by Horta (1979), based on Maslow's hierarchy of needs, can support the healthcare practice using NP in the pursuit of solving problems and meeting the biopsychosocial needs listed $^{(7)}$.

Nurses are trained to have a comprehensive and perceptive vision about the various nuances of the individual, which allows them, in this way, to sort the human responses using a taxonomy, which is a way to classify or sort topics into categories. The preparation of ND instrumentalizes and directs the other steps of NP, including the planning of assistance, that is, the determination of the expected outcomes and nursing interventions as well as the evaluation of the efficiency of the care provided ${ }^{(9)}$.

In the context of renal therapies, NP, in particular the establishment of NDs, constitutes an essential tool for guiding the completion of treatment and to meet individual needs. ND occur from a clinical judgement of the responses of an individual, family, group or community, and may be a ND focused on the problem, ND of risk and ND of health promotion. Obtaining and classifying these diagnoses according to their priority are important to organize the sequence and the manner in which interventions should occur; also, they provide quantifiable criteria for the assessment of the assistance and the effectiveness of interventions, encouraging the health team to explore this feature, and the patient, to understand and participate in his treatment ${ }^{(9)}$.

From this context, it is believed that the determination of a profile of NDs in group and scientific context, listing the most recurrent, enables the improvement of care in the individual scope $^{(9)}$.

In particular, the establishment of NDs is a tool for the care to be provided to older adult patients with CKD who are undergoing hemodialysis treatment, making interventions responsibilities of the nurse - occur in a systematized way, and much more efficiently. That is because the professionals become tools by this pattern of diagnostics, which directs it to the points that need more attention in gathering data in this group of patients. There is also a reduction in the occurrence of clinical disagreements caused by ignorance of the specific features of healthcare practice setting ${ }^{(10)}$.

Also, by obtaining these NDs, research and teaching can be simplified, since the needs and characteristics of this group of patients are highlighted through these diagnoses. This does not exclude that there are other diagnoses besides the ones classified as more recurrent. However, the outline of a profile optimizes the process by reducing the use of inaccurate diagnoses, inadequate results and ineffective interventions, which 
lead to loss of diagnoses that would be more important to the older adult under hemodialysis treatment ${ }^{(9)}$.

Therefore, this study presented the following research question: What are the main NDs of older adults who undergo hemodialysis?

It is understood that the research results might collaborate with training and instrumentalizing of nurses - professionals in direct contact with these patients in the provision of care. We must consider the level of fragility and vulnerability of this population under hemodialysis treatment, which requires technical and relational skills of the specific features of the older adults ${ }^{(11-13)}$.

\section{OBJECTIVE}

To identify the main nursing diagnosis of older adult patients with CKD who are undergoing hemodialysis treatment attended at a dialysis unit of a public hospital in the countryside of the state of São Paulo.

\section{METHOD}

\section{Ethical aspects}

The project was submitted for consideration and analysis by the Committee of Ethics in Research with Human Beings of the EERPUSP, having been approved. Data collection started after approval. It was then applied the informed consent form to the older adults, according to the requirements of Resolution CNS 466/12. Participants, by agreeing it, signed two copies of the form, one given to the participant and the other remaining with the researchers.

\section{Outline, research site and period}

Exploratory descriptive study, which used, for data collection, strategy case studies, that, according to Polit and Hungler (1995), aims to obtain information about the prevalence, distribution and interrelationships of variables of a population ${ }^{(14)}$.

The study was conducted in the dialysis unit at the Hospital das Clínicas of Ribeirão Preto Medical School, University of São Paulo, in the period from April to May 2016.

\section{Population, inclusion and exclusion criteria}

It were included older adult patients in chronic treatment by hemodialysis that met the following inclusion criteria: age equal to or more than 60 years; be in treatment for at least six months and be in stable clinical condition, i.e., not presenting acute, psychological or physical complications that make it impossible to answer the questionnaire.

In the dialysis unit, in March 2016, there were 102 patients in hemodialysis. Of these, 39 were older adults and 28 met the criteria and participated in this study. There were seven patients excluded, being four for having some kind of dementia and three for having severe auditory deficit. There have been four losses, one by death and three for refusing to participate in the research.

\section{Study protocol}

The sampling was characterized as convenience. Data collection procedure was carried out by two undergraduate students in nursing, students of the seventh period of the course of Bachelor's Degree in Nursing at EERP-USP, duly qualified and under the supervision of a faculty advisor.

For data survey, it was conducted an interview and physical examination of the older adults. The interview was held in hemodialysis room, within the initial 2 hours of a session of hemodialysis, and the physical examination was held in this same room, with the use of screens, during dialysis sessions. Data collection had an average of 40 to 50 minutes.

For data collection, we used a systematic instrument, drawn from the professional experience and review of the literature, containing the socioeconomic characterization and clinical variables as well as physical examination, in the light of the Conceptual Model of Wanda Horta(7) using the data collection according to the basic human needs (BHN). This instrument was organized to include the following topics:

I. Identification data and health history: age, skin color, marital status, origin, education, profession and/or occupation, health history and current complaint, habits and lifestyle.

II. Objective and subjective data related to the BHN:

- Psychobiological needs: oxygenation/breathing, movement, thermoregulation, sensory perception, tissue integrity, nutrition/hydration, elimination, sleep/rest, physical activity/mobility, hygiene, regulation, shelter, sexuality;

- Psychosocial needs: security, communication, social interaction, leisure/recreation, self-esteem, self-actualization;

- Psychospiritual needs: religious belief, spiritual need.

\section{Analysis of the results and statistics}

Data analysis and proposition of the main nursing diagnoses proceeded in two stages, which are the processes of data evaluation and interpretation, to give them meaning, allowing to reach conclusions about the health condition of the patient, according to Risner (1990): Step 1: Phase I - Data analysis and synthesis: grouping related data; comparing with normal standards; survey of nursing diagnostic hypotheses; and establishment of relationship with CKD and dialysis. Step 2: Phase II - Establishment of nursing diagnoses using the taxonomy of NANDA-I (2015) and considering its components (title, related factors and defining characteristics) ${ }^{(15)}$.

The NDs were drafted having been necessary the completion of some information and/or clarification of data collected, which were sought in unit of the study. The NDs were reviewed and verified by two professionals of the field.

Descriptive analyses were conducted of the characteristics of the older adults and of the NDs of absolute and percentage frequency as well as their categorization.

\section{RESULTS}

Among the 28 older adults that participated in the study, 17 $(60.71 \%)$ were female and $11(39.29 \%)$ were male. The average age of the participants was 70.2 years old, being 60 years the lowest age and 86 years the highest.

The time of the hemodialysis therapy among the older adults ranged between two and 25 years. Of the participants 
of the study, six (21.5\%) had had medical follow-up by socialized healthcare/private care before starting dialysis, 15 (53.5) had follow-up by SUS and seven (25\%) had no follow-up before the appearance of the first symptoms of CKD (Table 1).

Table 1 - Distribution of sociodemographic variables of 28 older adults on hemodialysis, Ribeirão Preto, São Paulo, Brazil, 2016

\begin{tabular}{lcc}
\hline Variables & $\mathbf{n}$ & \% \\
\hline Sex & & \\
$\quad$ Female & 17 & 60.71 \\
$\quad$ Male & 11 & 39.29 \\
Pre-follow-up of CKD* & & \\
$\quad$ SUS** & 15 & 53.5 \\
$\quad$ Socialized healthcare & 6 & 21.5 \\
$\quad$ Not done & 7 & 25.0 \\
Marital Status & & \\
$\quad$ Single & 1 & 3.6 \\
$\quad$ Married & 17 & 60.7 \\
$\quad$ Divorced & 4 & 14.2 \\
$\quad$ Widower & 6 & 21.5 \\
Total & 28 & 100 \\
\hline
\end{tabular}

Note: ${ }^{*}$ Chronic kidney disease; ${ }^{* *}$ Unified Health System.

Regarding the NDs of the 28 older adults undergoing treatment by hemodialysis, it was identified a total of 110 NDs, with an average of 3.9 ND per older adult.

Seven different NDs have been identified, in which four $(57 \%)$ are based on the problem, here: Excessive fluid volume, constipation, walking impairment, and chronic pain; and three $(43 \%)$ risk diagnoses, being: Risk of infection, risk of electrolyte imbalance and risk of impaired skin integrity (Table 2).

Table 2 - Distribution of NANDA-I nursing diagnoses (2015), identified in 28 older adults in hemodialysis, Ribeirão Preto, São Paulo, Brazil, 2016

\begin{tabular}{lcc}
\hline NANDA-I nursing diagnoses (2015) & $\mathbf{n}$ & $\mathbf{\%}$ \\
\hline Risk of infection & 28 & 25.5 \\
Excessive fluid volume & 28 & 25.5 \\
Risk of electrolyte imbalance & 26 & 23.7 \\
Constipation & 10 & 9.7 \\
Risk for impaired skin integrity & 6 & 5.5 \\
Walking impairment & 6 & 5.5 \\
Chronic pain & 5 & 4.6 \\
\hline
\end{tabular}

Concerning the areas of the NDs identified, it is highlighted the number two related to the patient's Nutrition, with $49.2 \%$ of NDs, and the domain of number 11 related to Safety/Protection, which accounted for $31 \%$ of NDs (Table 3 ).
Table 3 - Frequency distribution of nursing diagnoses identified in 28 older adult patients in dialysis, according to the NANDA-I domains (2015), Ribeirão Preto, São Paulo, Brazil, 2016

\begin{tabular}{lcc}
\hline NANDA-I domains (2015) & $\mathbf{n}$ & \% \\
\hline Nutrition & 54 & 49.2 \\
Safety/Protection & 34 & 31.0 \\
Elimination and Exchange & 10 & 9.7 \\
Activity/Rest & 6 & 5.5 \\
Comfort & 5 & 4.6 \\
\hline
\end{tabular}

Before the results, the NDs Risk of infection, Excessive fluid volume and Risk of electrolyte imbalance were considered the main NDs identified in elders undergoing hemodialysis and that, in this study, directed a discussion on related aspects and its causative factors in the pursuit of instrumentalize the performance of professional nurses.

\section{DISCUSSION}

The predominant sex of the older adults of this study was female, according to demographic trend of the world's population, characterizing the phenomenon called feminization of old age. On the other hand, this is not a common feature among patients with CKD, in which there is higher prevalence of males. However, there is no scientific justifications that can demonstrate if there are gender differences related to CNCDs or even in relation to the CKD in particular ${ }^{(16-18)}$.

As for the main NDs found in this study, the results confirm what was noted in current literature ${ }^{(19)}$. Hence, these results are important elements to be considered when applying nursing process that must be used in the care of the older adult patient in hemodialysis therapy.

It was observed the importance that is necessary to assign to the diagnosis of Risk of infection, considering the chronic condition of kidney disease as an acquired risk factor, coupled with frequent exposure to the hospital environment for hemodialysis therapy and the punctures of the arteriovenous fistula (AVF) as the primary means of vascular access to treatment. When not, a catheter is used, which is a usually temporary option for patients who do not have AVF, and the main complications related to the use of this catheter are obstruction and infection ${ }^{(18,20)}$.

In addition to the risk of infection factors cited, we should consider the fact that this is a patient who has senescent characteristics, such as the delay of immunological responses, which occurs in older adults, because the response of neutrophils and monocytes becomes inadequate to the action of bacteria and fungi during the aging process. Another aggravating factor is the CNCDs, as SAH and the DM, observed in the majority of older adults, in addition to the effects of the medicines used to control the CNCDs and those that are required considering hemodialysis therapy itself. In this way, the elderly is more susceptible to developing infections related to healthcare. It is noteworthy that the infection is the second 
leading cause of death in patients with chronic renal disease and is strongly related to vascular access ${ }^{(5)}$.

The ND of Excessive fluid volume were also present in all the older adults, confirming the literature - for example, according to Fernandes (2014), the accumulation of fluids is a frequent finding in hemodialysis patients ${ }^{(21)}$.

Cavalcanti (2015) noted in his study that the ND of Excessive fluid volume had a higher incidence in older women who presented clinical conditions such as SAH and DM, a result also noticed in our analysis. This can be explained by the fact that blood pressure is directly related to the homeostasis of bodily fluid, which is maintained by the relationship between the volume of ingested and eliminated liquids, and this balance is regulated by the nervous system, hormone controls and by the kidneys. Thus, once the glomerular filtration rate is lower or null in patients with CKD, the elimination of fluids and electrolytes becomes inefficient, causing accumulation in the body and causing increased blood pressure in the interdialytic period ${ }^{(21-22)}$.

Being older adults the patients on hemodialysis with lower rate of survival and considering the frequent presence of the ND Excessive fluid volume, it is noted the need for early identification and effective management based on scientific knowledge of this diagnosis by the health team, since the body fluid overload in interdialytic period may cause edemas - among them, acute pulmonary edema, which is a common cause of hospitalization of older adult patients on hemodialysis ${ }^{(21-22)}$.

Therefore, the ND of Excessive fluid volume is considered a risk factor for the ND of Risk of electrolyte imbalance, and, as observed, $92.8 \%$ of the older adults participants of this study had such ND. This is also related to the regulator mechanism compromised by renal dysfunction, increasing the vulnerability of the patient related to reduced elimination of serum electrolytes, essential in maintaining homeostasis of the body $y^{(9)}$.

Hemodialysis therapy is substitutive and instituted to patients who have their kidney function compromised; however, although very effective, the treatment does not replace completely the kidney function, triggering constantly the risk of electrolyte imbalance, since hemodialysis does not guarantee elimination of excess electrolytes continuously as the physiological function. According to what was observed in laboratory tests, most patients can present major changes in dosages of electrolytes circulating because their regulation occurs primarily through renal filtration and subsequent urinary elimination ${ }^{(21)}$.

For patients with residual renal function, the misuse of diuretics in an attempt to regulate electrolyte levels along with the water intake less than the recommended due to CKD can expose older adults to electrolyte disorder. Besides the factor of old age, making the food intake - by the dysfunction of thirst regulation mechanism - and the absorption of liquids naturally reduced. Furthermore, the losses due to diarrhea, a complaint of patients undergoing hemodialysis therapy, can predispose to the risk of electrolyte imbalance, compromising their health ${ }^{(23)}$.

For older adults, it should be considered all the risk factors associated with hemodialytic therapy, plus the presence of diseases and specific characteristics of aging, such as polypharmacy, multiple comorbidities, the increased use of health services and the high rate of hospitalization, when compared with the younger population. This study covers the aspects related to the main NDs of older adults undergoing hemodialysis, which can base the remaining steps of NP, namely, the elaboration of the assistance planning, the implementation of the nursing interventions and evaluation of care provided ${ }^{(23-24)}$.

\section{Limitations of the study}

In this study, the most common NDs were those considered the main ones and directed the discussion of results. However, it is necessary to emphasize the relevance of all the NDs developed, especially in the domains nutrition and safety/protection, considering the conditions of chronicity of the older adult on hemodialysis treatment. It is also important to indicate as limitation the not completion of the study of accuracy of the main NDs listed, which can compose a next stage of research.

\section{Contributions to the field of nursing}

This study can instrumentalize the performance of nurses, who play an important role in the leadership of the team, in order to direct the care through the promotion, maintenance and restoration of the balance of the patient's health on hemodialysis during the aging process, thus contributing to the practice of nursing as a science and autonomously. Further research can identify other NDs related to physiological modifications that occur in the older adult patient as well as with distinct dialytic realities. Anyway, the research results of this nature have the potential to provide a better quality of life of this population through scientific and theoretical knowledge that guide nursing practice and promote improvements in the health of these older people ${ }^{(23)}$.

\section{CONCLUSION}

The main NDs identified in older adults undergoing hemodialysis were: Risk of infection, Excessive fluid volume and Risk of electrolyte imbalances, which have been associated with related factors and defining characteristics of NANDAI (2015), in search of the instrumentalization of the performance of the nursing staff.

Nurses, who have a major role in the care of older adults, should consider the main NDs here listed to subsidize the planning of care; however, the individualized care should encompass the other NDs present in each elder and thus provide the patients a care directed at their needs of affected health. It is worth also to highlight that the modifications of senescence and senility in addition to clinical evidence listed should be considered in the survey of NDs in a precise way, directing the implementation of care in order to obtain positive results in the evaluation of the care provided.

The knowledge of these NDs assists the health care under prevention and rehabilitation, since they were listed as risk diagnostics and problem-based diagnostics, all of them considering the characteristics of the older adult patient. In addition, there is the contribution of nursing as a science in the care process, approaching the nurse with the patient and with clinical evidence. 


\section{REFERENCES}

1. Werneck F. Nefrologia em Geriatria. RJ: editora Rubio; 2008.

2. Kirsztajn GM, Filho NS, Draibe AS, Netto MVP, Thomé FS, Souza E, MG Bastos. Leitura rápida do KDIGO 2012: Diretrizes para avaliação e manuseio da doença renal crônica na prática clínica. J Bras Nefrol [Internet]. 2014 [cited 2017 Jan 10];36(1):63-73. Available from: http://www.scielo.br/pdf/jbn/v36n1/0101-2800-jbn-36-01-0063.pdf

3. Carvalho FP, Carvalho ILN, Sousa ASJ, Simões CD, Silva ES, Santos JAF. Avaliação da capacidade funcional de idosos com doença renal crônica em tratamento de hemodiálise. Saúde (Santa Maria) [Internet]. 2016 [cited 2017 Jan 10];42(2):175-84. Available from: https://periodicos.ufsm.br/revistasaude/article/view/21515

4. Sesso RC, Lopes AA, Thomé FS, Lugon JR, Martins CT. Inquérito Brasileiro de Diálise Crônica 2013: análise das tendências entre 2011 e 2013. J. Bras. Nefrol [Internet]. 2016 [cited 2017 Jan 10];38(1):54-61. Available from: http://www.scielo.br/pdf/jbn/ v38n1/0101-2800-jbn-38-01-0054.pdf

5. Ajzen H, Nestor S. Guias de Medicina ambulatorial e hospitalar. UNIFESP: Editora Série Nestor Schor. 2.ed. 2005.

6. Lemes MMDD, Bachion MM. Hemodialysis nurses rate nursing diagnoses relevant to clinical practice. Acta Paul Enferm [Internet]. 2016 [cited 2017 Jan 10];29(2):185-90. Available from: http://www.scielo.br/pdf/ape/v29n2/en_1982-0194-ape-29-02-0185.pdf

7. Horta WA. Processo de enfermagem. São Paulo: EPU 1979; 99p.

8. Alfaro-Lefevre R. Aplicação do processo de enfermagem. Artimed. 7.ed; 2010.

9. NANDA-I, Inc. Diagnósticos de enfermagem da NANDA: 2015-2017. Porto Alegre: Artmed; 2015.

10. Carvalho EC, Kusumota L. Processo de enfermagem: resultados e consequências da utilização para a prática de enfermagem. Acta Paul Enferm [Internet]. 2009 [cited 2017 Jan 10];22(Especial-Nefrologia):554-7. Available from: http://www.scielo.br/pdf/ ape/v22nspe1/22.pdf

11. Pilger C, Rampari EM, Waidman MAP, Carreira, L. Hemodiálise: seu significado e impacto para a vida do idoso. Esc Anna Nery (impr.) 2010 out-dez; 14(4):677-683.

12. Orlandi FS, Gesualdo GD. Assessment of the frailty level of elderly people with chronic kidney disease undergoing hemodialysis. Acta Paul Enferm [Internet]. 2014 [cited 2017 Jan 10];27(1):29-34. Available from: http://www.scielo.br/pdf/ape/v27n1/01032100-ape-27-01-00029.pdf

13. Kusumota L, Oliveira MP, Marques S. O idoso em diálise. Acta Paul Enferm[Internet]. 2009 [cited 2017 Jan 10];22(EspecialNefrologia):546-50. Available from: http://www.scielo.br/pdf/ape/v22nspe1/20.pdf

14. Polit DF, Hungler BP. Fundamentos de pesquisa em enfermagem. Porto Alegre: Artes Médicas; 1995.

15. Risner PB. Diagnosis and synthesis of data. In: Christensen PJ, Kenney JW. Nursing process: conceptual models. 4.ed. St. Louis: Mosby; 1990. cap.7, p.132-57.

16. Lebrão ML. O envelhecimento no Brasil: aspectos da transição demográfica e epidemiológica. Saúde Coletiva 2007;04(17):135-140.

17. Veras R. Envelhecimento populacional contemporâneo: demandas, desafios e inovações. Rev Saúde Pública [Internet]. 2009 [cited 2017 Jan 10];43(3):548-54. Available from: http://www.scielo.br/pdf/rsp/v43n3/en_224.pdf

18. Fernandes MGM. Diagnósticos de enfermagem do domínio atividade/repouso evidenciados por idosos em tratamento hemodialítico. Rev Rene [Internet]. 2012 [cited 2017 Jan 10];13(4):929-37. Available from: http://www.periodicos.ufc.br/index. php/rene/article/view/4063

19. Poveda VB, Alves JS, Santos EF, Garcia AEM. Diagnósticos de enfermagem em pacientes submetidos à hemodiálise. Enferm Global [Internet]. 2014 [cited 2017 Jan 10];(34):70-81. Available from: http://revistas.um.es/eglobal/article/viewFile/167841/160251

20. Sociedade Brasileira de Nefrologia (SBN). Hemodiálise [Internet]. 2016 [cited 2016 Nov 19]. Available from: http://sbn.org.br/ publico/tratatamentos/hemodialise/.

21. Fernandes MID. Prevalence of nursing diagnosis of fluid volume excess in patients undergoing hemodialysis. Rev Esc Enferm USP [Internet]. 2014 [cited 2017 Jan 10];48(3):446-53. Available from: http://www.scielo.br/pdf/reeusp/v48n3/0080-6234reeusp-48-03-446.pdf

22. Cavalcanti MIF. Pacientes em hemodiálise com diagnóstico de enfermagem volume de líquidos excessivo: aspectos socioeconômicos e clínicos. Cogitare Enferm [Internet]. 2015 [cited 2017 Jan 10];20(1):161-70. Available from: http://revistas. ufpr.br/cogitare/article/view/37627

23. Clares JWB, Freitas MC. Diagnósticos de enfermagem do domínio Nutrição identificados em idosos da comunidade. Rev Eletr Enferm [Internet] 2013 [cited 2017 Jan 10];15(4):940-7. Available from: http://dx.doi.org/10.5216/ree.v15i4.20513

24. Guimarães DL. Contribution of Horta theory for critical of nursing diagnostics patient in hemodialysis. Rev Enferm UFPE [Internet]. 2016 [cited 2017 Jan 10];10(2):554-61. Available from: http://www.revista.ufpe.br/revistaenfermagem/index.php/revista/article/ view/8802/pdf_9588 